\title{
CHEMICAL DEPOSITS IN VOLCANIC CAVES OF ARGENTINA
}

\author{
Carlos Benedetto *, Paolo Forti ${ }^{* *}$, Ermanno Galli ${ }^{* * *}$, Antonio Rossi ${ }^{* * *}$
}

\begin{abstract}
During the last Conference of the FEALC (Speleological Federation of Latin America and Caribbean Islands) which was held in the town of Malargue, Mendoza, in February 1997, two volcanic caves not far from that town were visited and sampled for cave mineral studies.

The first cave (Cueva del Tigre) opens close to the Llancanelo lake, some $40 \mathrm{kms}$ far from Malargue and it is a classical lava tube. Part of the walls and of the fallen lava blocks are covered by white translucent fibres and grains.

The second visited cave is a small tectonic cavity opened in a lava bed some $100 \mathrm{~km}$ southward of Malargue. The cave "El Abrigo de el Manzano" is long no more than 10-12 meters with an average width of 3 meters and it hosts several bird nests, the larger of which is characterized by the presence of a relatively thick pale yellow, pale pink flowstone.

Small broken or fallen samples of the secondary chemical deposits of both these caves have been collected in order to detect their mineralogical composition.

In the present paper the results of the detailed mineralogical analyses carried out on the sampled material are shortly reported.

In the Cueva del Tigre lava tube the main detected minerals are Sylvite, Thenardite, Bloedite and Kieserite, all related to the peculiar dry climate of that area.

The flowstone of "El Abrigo de el Manzano" consists of a rather complex admixture of several minerals, the large majority of which are phosphates but also sulfates and silicates, not all yet identified. The origin of all these minerals is related to the interaction between bird guano and volcanic rock.
\end{abstract}

Keywords: cave minerals, volcanic caves, Argentina

\section{INTRODUCTION}

During the last Conference of the FEALC (Speleological Federation of Latin America and Caribbean Islands) which was held in the town of Malargue, Mendoza, in February 1997 (Forti \& Rivalta 1997), two volcanic caves not far from that town have been visited (Fig. 1).

The first cave (Cueva del Tigre) opens close to the Llancanelo lake, some $40 \mathrm{kms}$ far from Malargue, its geographical co-ordinates being $69^{\circ} 19^{\prime} 02^{\prime \prime} \mathrm{W}$ and $35^{\circ} 45^{\prime} 48^{\prime \prime} \mathrm{S}$; and it is a classical lava tube consisting of a subhorizontal gallery with a total length of about 300 meters and an average diameter of 6-8 meters (Fig. 2). The entrance of the cave is a vertical pit of 6-7 meters reaching the central part of the tube and it has been adapted for the tourism by fixing metallic ladders to its wall: unfortunately the tourist activity inside the cave led to its heavy pollution at least in the first tens of meters from the entrance. In the inner part of the cave portions of the walls and of the fallen lava blocks are covered by white translucent fibres and grains (Fig. 3) of bitter salty minerals.

The second visited cave (El Abrigo de el Manzano) is a small tectonic cavity

* INAE, Malargue, Argentina.

** Italian Institute of Speleology, University of Bologna, Italy.

${ }^{* * *}$ Earth Science Department, University of Modena, Italy. 


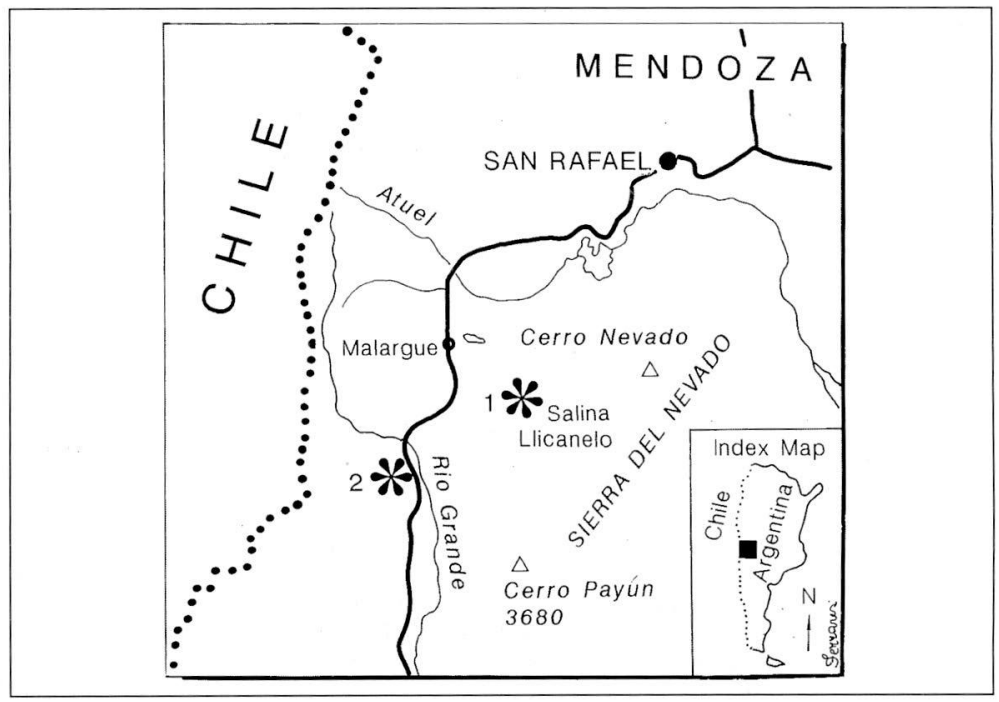

Fig. 1 - Location map for the two volcanic caves : 1 Cueva del Tigre ; 2- El Abrigo de el Manzano.

opened in a lava bed of about 20 meters of high few meters apart of the National Route 40 some $100 \mathrm{~km}$ southward of Malargue (Fig. 4): its geographical co-ordinates are $69^{\circ} 43^{\prime} 06^{\prime \prime} \mathrm{W}$ and $35^{\circ} 04^{\prime} 24^{\prime \prime} \mathrm{S}$. The hosting rock is a basalt with a transitional composition between alcaline and sub-alcaline rocks, which may be defined as trachibasalt (Irvine \& Baragar 1971). The cave (Fig. 5) is long no more than 10-12 meters with an average width of 3-4 meters and it's known for hosting a small red painting, which is not in good condition nowadays. The cavity is presently a shelter for different animals and in particular it hosts several bird nests, the larger of which is characterized by the presence of a relatively thick pale yellow-pale pink flowstone some tens of centimeters long (Fig. 6).

Small broken or fallen samples of the secondary chemical deposits have been collected from both these caves in order to detect their mineralogical composition.

In the present paper the results of the detailed mineralogical analyses (still in progress) of the sampled materials are shortly reported.

\section{SAMPLE ANALYSES}

Samples from the Cueva del Tigre lava tube consist of well crystalline materials therefore it was sufficient to analyze them by means of X-ray powder diffraction in order to detect their mineralogical composition.

Beside gypsum, which was known from that cave long since, the detected minerals are : Sylvite, Thenardite, Bloedite and Kieserite. All these minerals have been already known from lava tubes and their origin is related to the peculiar dry climate of that area, which allow a fast evaporation of the seeping water reaching the cave, while all the involved ions come from the weathering of the lava bed (Hill and Forti, 1997).

More complex resulted the analysis of the flowstone found in the "El Abrigo de el 
Manzano" which consists of a rather complex admixture of several minerals, the large majority of which are phosphates.

At the naked eye this flowstone consist of several thin layers, the color of which may greatly change following their chemical variance : from whitish to pale ivory to pink to reddish-brown.

The observation with the binocular microscope put in evidence that the different layers often have a different structure (globular, terrigenous, fibrous, strongly to weakly cemented).

The observation of thin sections perpendicular to the layers shown the presence of

Fig. 2 - Inside the Cueva del Tigre lava tube.
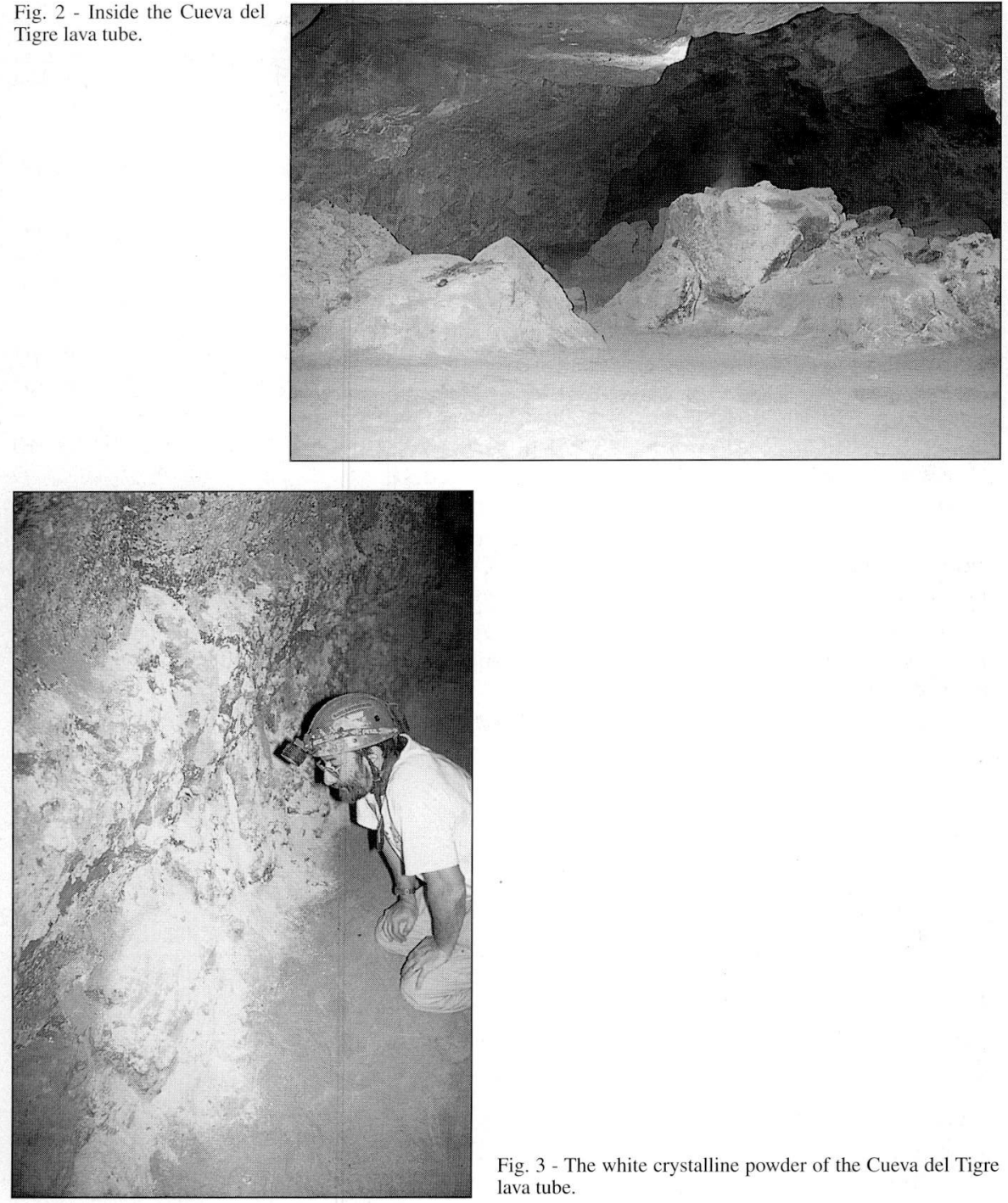

Fig. 3 - The white crystalline powder of the Cueva del Tigre lava tube. 


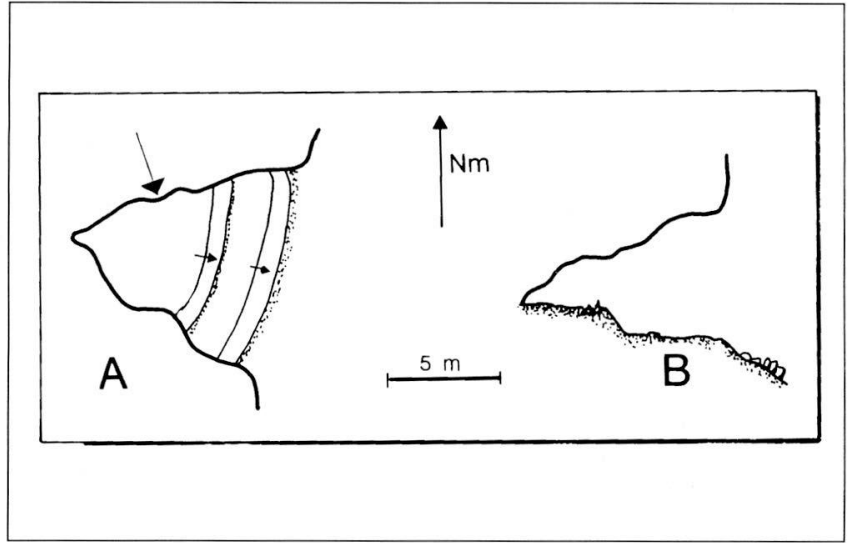

Fig. 4 - Plan and vertical section of the El Abrigo de el Manzano cave (after Urbani \& Benedetto 1998).

widespread tension cracks, the existence zones rich in spherical cavities, and areas with redissolutional and/or corrosional features.

The X-ray diffraction over powdered samples selected by using the binocular microscope to reduce their compositional variability gave scarce results due to the impossibility to have enough pure materials and due to the presence of scarcely crystalline compounds.

Better results were achieved by combining the X-ray diffraction (obtained by the Gandolfi camera) over a few of single crystals selected under the binocular microscope with the SEM observation and EDS semiquantitative analyses.

Up to now over 500 samples have been selected for the SEM and EDS analyses, 40 of which have been also used for the X-ray diffraction.

The SEM analyses shown that the speleothem sometimes consists of an admixture of very small (few microns or few tens of microns) euhedral crystals of different minerals even if more frequently it is composed by spherical or tubular structures which are clearly remnants of the microbiological activity inside the guano.

The EDS analyses put in evidence that most of the speleothem consists of phosphates with some sulfates, urates, chlorides and silicates; some organic compounds are also present.

The presently identified minerals are listed in Tab. 1 together with their chemical composition and peculiar characteristics.

Tab. 1- The presently identified minerals of the volcanic cave "El Abrigo de el Manzano"

\begin{tabular}{|l|l|l|}
\hline Mineral & Chemical composition & Occurrence \\
\hline Carbonate-hydroxilapatite & $\mathrm{Ca}_{5}\left(\mathrm{PO}_{4}, \mathrm{CO}_{3}\right)_{3}(\mathrm{OH})$ & in a pale-yellow layered crust mixed to syngenite \\
\hline Brushite (Fig.7A) & $\mathrm{CaHPO}_{4} .2 \mathrm{H}_{2} \mathrm{O}$ & stocky tabular monoclinic crystals \\
\hline Hannayite (Fig.7B) & $\left(\mathrm{NH}_{4}\right)_{2} \mathrm{Mg}_{3} \mathrm{H}_{4}\left(\mathrm{PO}_{4}\right)_{4} .8 \mathrm{H}_{2} \mathrm{O}$ & transparent, vitreous crystals \\
\hline Monetite (Fig.7C) & $\mathrm{CaHPO}_{4}$ & tabular whitish elongated prismatic euhedral crystals \\
\hline Sulfur (Fig.7D) & $\mathrm{S}$ & yellow crypto-crystalline aggregates \\
\hline Syngenite (Fig.7E) & $\mathrm{K}_{2} \mathrm{Ca}_{(}\left(\mathrm{SO}_{4}\right)_{2} . \mathrm{H}_{2} \mathrm{O}$ & tabular transparent vitreous euhedral prismatic crystals \\
\hline Uricite (Fig. 7F-G) & $\mathrm{C}_{5} \mathrm{H}_{4} \mathrm{~N}_{4} \mathrm{O}_{3}$ & small aggregates of transparent monoclinic crystals \\
\hline
\end{tabular}


Fig. 5 - Overview on the Rio Grande valley from El Abrigo de el Manzano.
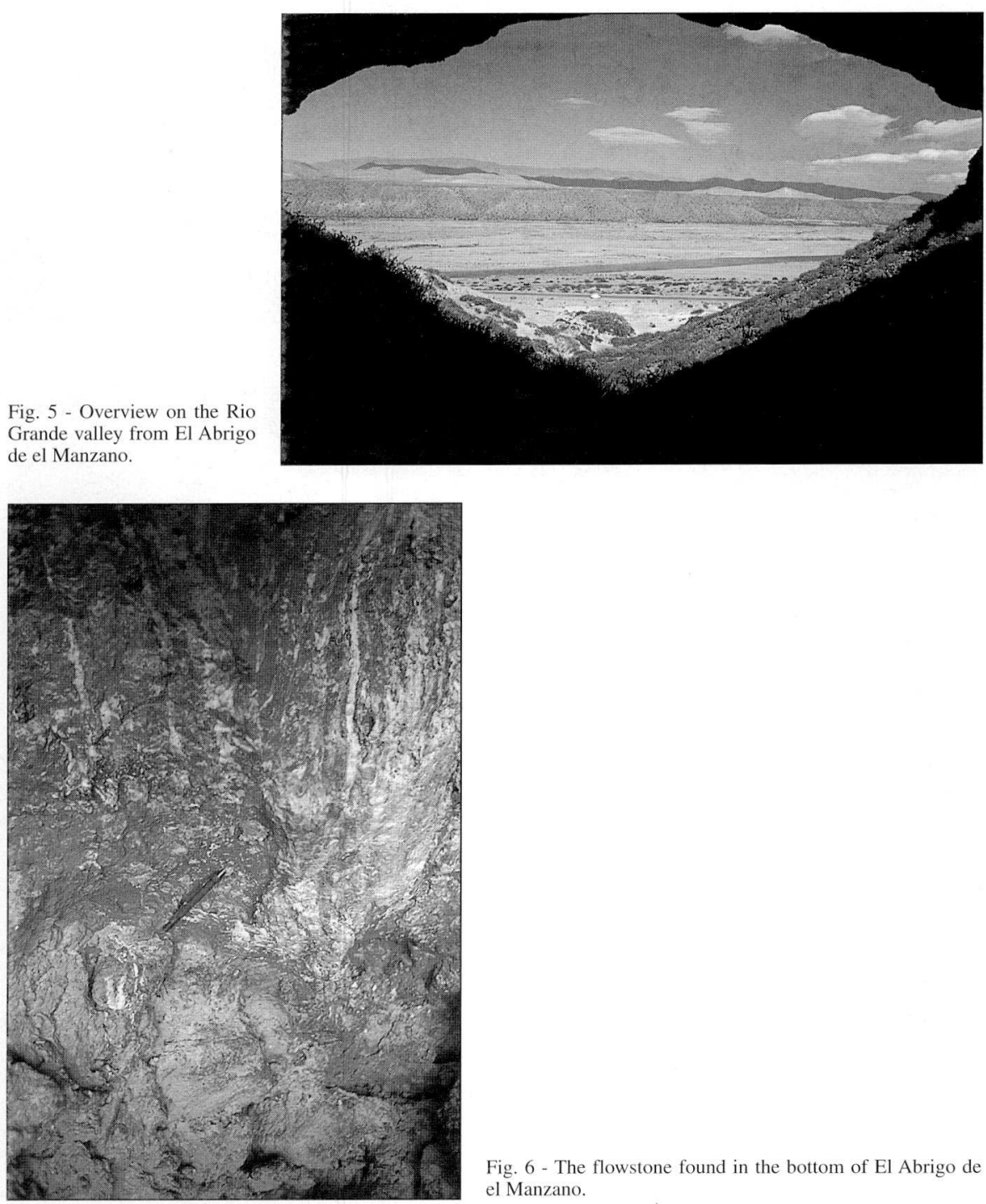

Fig. 6 - The flowstone found in the bottom of El Abrigo de el Manzano.

Fairly common are also aggregates of small spheres (Fig. 7H), the chemical composition of which is variable from spot to spot, being always high in organic matter. They seem to be produced by the chemical precipitation of different minerals over some living microorganisms, which has been identified as colonies of coccoidal bacteria, similar to those living over ancient glasses (Krumbein et al. 1991). These bacteria evidently live not only over artificial glass but also over natural (volcanic) glass: the El Abrigo de el Manzano is the first place in which coccoidal colonies are surely identified in a cave environment.

Inside the speleothems several elongated organic fibers related to other bacteria or fungi have been also observed. 


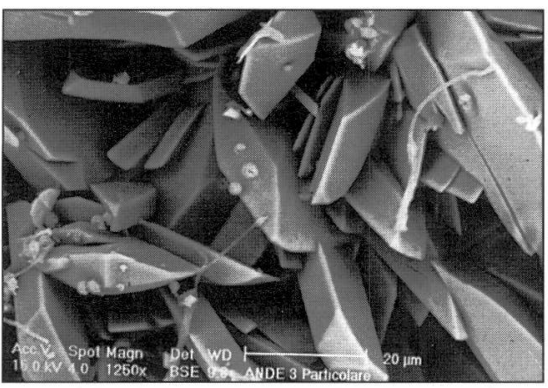

A) Brushite with some organic filaments.

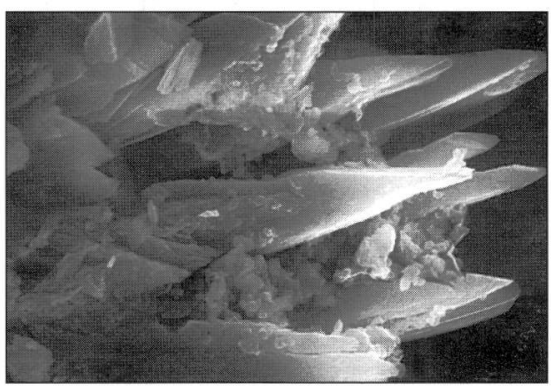

C) Monetite.

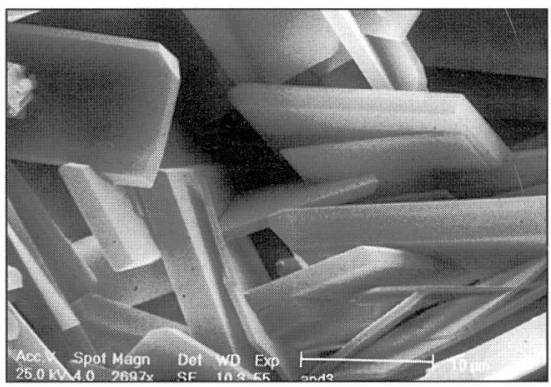

E) Syngenite.

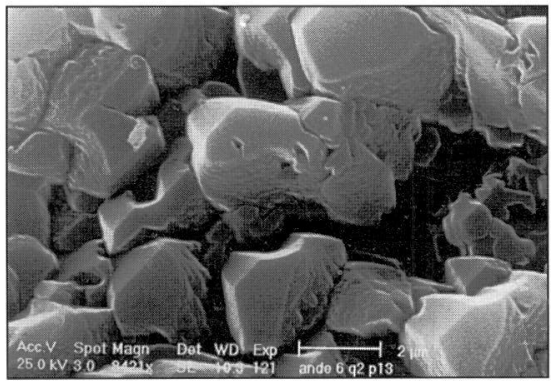

G) Enlargement of F.

Fig. 7- SEM images from el Abrigo de el Manzano.

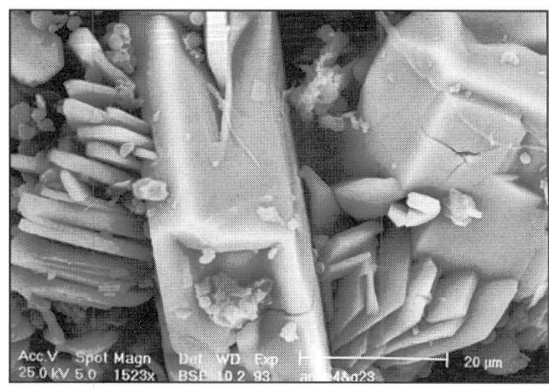

B) Hannayte.

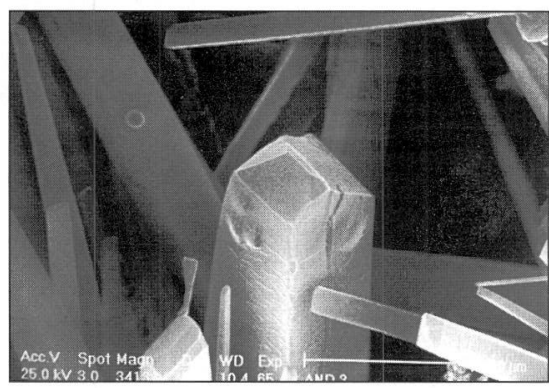

D) Single crystal of Sulfur.

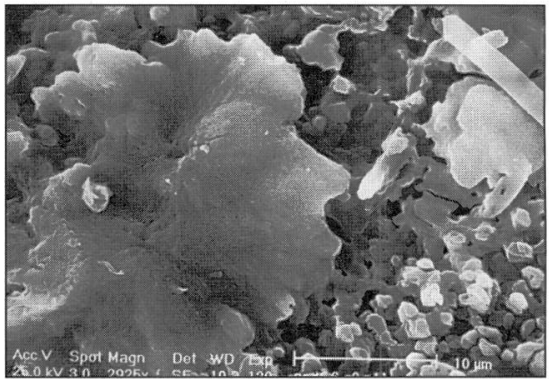

F) Uricite.

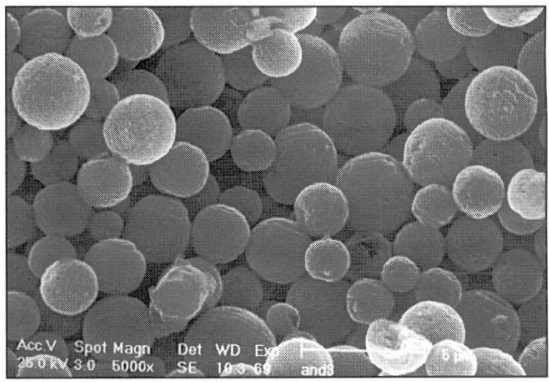

H) Coccoidal bacteria. 


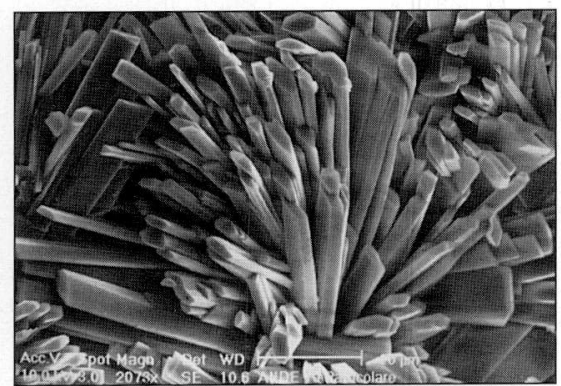

A) Organic compound.

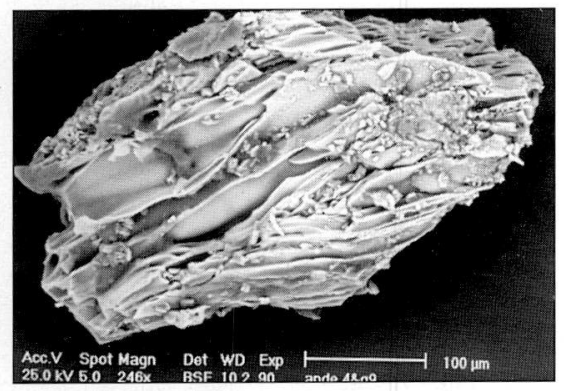

C) Amorphous silicate.

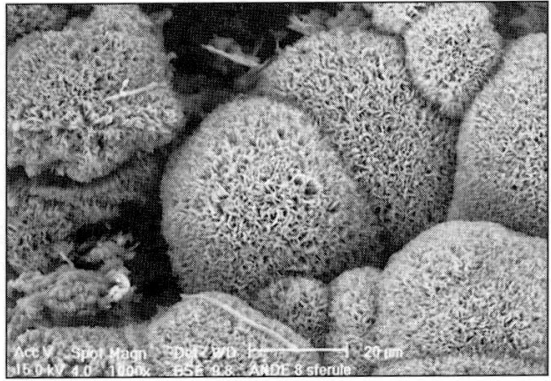

B) Organic compound.

Fig. 8 - SEM images of unidentified materials from El Abrigo de el Manzano.

Beside these minerals identified structures the flowstone is built up by someeveral other compounds not yet definitively identified.

Among them a potash and sodium phosphate two organic compounds, the first of which forms bidimensional radial aggregates of elongated prismatic greasy crystals (Fig. 8A), and the second of which consists of spheroidal aggregates of acycular crystals (Fig. 8B). Finally some part of the flowstone is composed by an amorphous potash sodium aluminum silicate, which forms vitreous weakly transparent layered uncemented structures (Fig. 8C).

Fairly common are also aggregates of small spheres, the chemical composition of which is variable from spot to spot : they seem to be produced by the chemical precipitation of different minerals over some living microorganisms.

Finally several other uncommon phases and crystals are waiting to be understood.

Anyway the origin of all the presently detected minerals, as well as that of those still not completely identified, is surely simply related to the interaction between bird guano and volcanic rock often controlled by micro-organisms as testified by SEM images of biogenic structures close to the well crystallized secondary minerals.

\section{FINAL REMARKS}

Even if the analyses are still in progress the achieved results allow to state that these two caves are already very important from the mineralogical point of view for Argentina, moreover the "El Abrigo de el Manzano" will probably become one of the richest caves in the world of different well crystallized cave phosphates and organic compounds. 


\section{ACKNOWLEDGMENTS}

The Authors are indebted to Dr Massimo Tonelli of the C.I.G.S. of the University of Modena for SEM photographs

\section{REFERENCES}

FORTI P., and G. Rivalta 1997 Dagli Appennini alle Ande - ovvero: le peregrinazioni carsico-scientifico-turistiche-collezionistiche di due speleologi di Bologna a Malargue. Sottoterra 104, p.20-25

HILL C.A. and P. Forti P. 1997 Cave Minerals of the World (second edition). National Speleological Society, $464 \mathrm{pp}$.

IRVINE T. N., and W. R. A. Baragar., 1971 A guide to the chemical classification of the common volcanic rocks. Can. J. Eath Sc., 8, p.523-528

KRUMBEIN W. E., C.E. Urzì and C. Gehrmann. 1991 Biocorrosion and Biodegradation of Antique and Medieval Glass. Geomicrobiology J. v.9, p.139-160

URBANI F., and C. Benedetto. 1998 Apuntes Mineralogicos sobre Algunas Cuevas del Departemente de Malargue, Mendoza, Argentina. Bull. Soc. Venez. Espel. In press. 